\title{
Economic Value of Dairy Cattle Business in the Lowlands Outside Java
}

\author{
Herawati T, Priyanto D, Purwantari ND \\ Indonesian Research Institute of Animal Production \\ PO Box 221 Bogor 16002, West Java, Indonesia \\ herawati_tati@yahoo.com
}

\begin{abstract}
The distribution of dairy cattle population in Indonesia is still concentrated in Java, almost 98.62\%. However, milk consumers are evenly in Java and outside Java. In addition, outside of Java has high availability of land as well as the source of the feed. Therefore, the government tries to develop a dairy cattle business outside Java. Dairy cattle development activities were carried out in the highland and also in lowland areas. Whereas, it is well known that the productivity of dairy cattle is optimal in the highland areas. The purpose of this research was to assess the feasibility of a dairy business in the lowland areas outside Java in terms of its productivity and economic analysis. Research was done in the farmer group of "Talago Sakato" Nagari Kayu, Padang Pariaman, West Sumatra Province. Data collection was done by 2015 in the form of location characteristics as secondary data and milk production as well as the value of the input-output dairy businesses as primary data. Descriptive data was used to analyse the location characteristic and non-parametric $t$ test was used to compare milk production in different area. The result shows the average milk production dairy cattle in lowland area of Padang Pariaman 10 litres/head/day was not significantly ifferent from the average milk production in Java (P 0.173). However, it was significantly lower compared to milk production in the highland areas in Java. It has a value of $\mathrm{B} / \mathrm{C} 0.30$ regardless of labor cost. If labor variable was taken into account, it required the addition of milk productivity at least 1056 liters/head/lactation period in order to be accomplished BEP. These values indicate that a dairy business in the lowland areas outside Java are rated quite feasible to be developed as seen from milk production values which do not vary markedly with milk production in the lowland areas in Java, but needs to be improved, among others, through the introduction of applied technology.
\end{abstract}

Key Words: Dairy Cattle, Lowland areas, Outside Java, Farming Analysis

\section{INTRODUCTION}

Report of the Ministry of Agriculture (2016) shows that the consumption of protein Indonesian inhabitants was $58.6 \mathrm{~g} / \mathrm{head} /$ day has exceeded $3.5 \%$ of the original target value i.e. $56.1 \mathrm{~g} / \mathrm{h}$ ead/day. This figure has also exceeded the number of recommended protein sufficiency as stated in national food and nutrition workshop VIII in 2004 (Widya Karya Nasional Pangan dan Gizi, WNPG) that amounted to $52 \mathrm{~g} /$ capita/day (LIPI 2004). From 2000 to 2004, deaths from dementia increased by $32.8 \%$. One of risk factors dementia was diet (macronutrient intakes). Several studies have shown that a higher intake of carbohydrate and protein not only to improve the general health but also to improve cognitive function and memories (Purnakarya 2009). Although it is known there has been an increase in the consumption of protein, if it is observed more in the highest protein consumption, during the last ten years is derived from proteins of vegetable and not of animal. Nutritional adequacy of animal protein still requires a sustained effort. One source of animal protein that rises is milk, from $27.4 \mathrm{kca} / \mathrm{head} /$ day in the year of 2011 to be 38.7 $\mathrm{kcal} / \mathrm{head} /$ day in 2015 . This happens due to the increased availability of protein $(0.89 \%)$ during the period 2010-2015. The increasing of the community's economic status makes the awareness of the need for good nutritional level. In addition, high population and growth rate of about $1.5 \%$, and high demand elasticity on livestock product, the demand 
for milk in Indonesia has increased. As a result, recently the total livestock and milk imports are increased. Due to a larger gap between domestic demand and supply of livestock, the Indonesia market is very attractive, especially if there is no serious work to increase domestic livestock production (Makka 2014).

The source of the milk is generally taken from dairy cattle, not many of which consume goat milk or from other. National milk production during last ten years hasnot been able to meet the demand, so imports of powdered milk have reached $70 \%$ of its needs. National milk production during the period of 2004-2005 only reached 485,717 tons/year, while the consumer demand of milk in the period was up 1,921,383 tons/year (Ditjennak 2008), which tend to be constant up to this point (Ditjen PKH 2015). These conditions indicate the need for improving national milk production effort to anticipate the growing gap widens between national milk production with consumer demand in the future. This is a wide open opportunity for the development of a dairy farm that leads to agribusiness venture of dairy cattle (Saragih 2001). Further confirmed by Pambudi et al. (2001) that the current farm business should already be entered into an industry farm which based on small farms. Such development must aim to increase farmer income breeders, encourage diversification, improvement of nutritional quality of the food community and develop export.

The distribution of dairy cattle population in Indonesia is still concentrated in Java, almost $98.62 \%$ (402,130 heads). While on the Island of Sumatra only $0.84 \%$ (3,450 heads) as well as other territories $0.54 \%$ (2,157 heads) (Gayatri et al. 2005). Now, the inhabitants of the Java Island reach the more dense, so the land was further distressed by the needs of farming settlement. It is therefore worth considering transfer of livestock development location to outside Java. Another factor is the potential area (land enterprises) as well as the feed support resources outside Java is still very high for the utilized and developed so as to provide a great contribution in the development of livestock including dairy cattle. Nevertheless, to note in the development of a commodity other than a source of feed is the suitability of the macro as well as micro-environment. Each commodity has environmental requirements to produce optimum productivity. Whereas it is well known that the productivity of dairy cattle is optimal in the highland areas. Atmadilaga (1959) quoted by Djaja et al. (2009) states that a high milk production will be produced by dairy cows in the area with an altitude of 750-1250 m above sea level, with temperatures ranging between $17-22^{\circ} \mathrm{C}$ and humidity $<55 \%$. This requirement is a basic consideration in the selection of the territory development of dairy cows. But other factors that are not less important is the ability of the farmers to raise dairy cattle. So many selected areas that are less suitable for the development of the macroclimate, but because in terms of human resources and the market is more possible, then the region was chosen as the region's development. This is a basis in determining policy recommendations for development of dairy cattles outside Java, in support of national milk needs to reduce imports from other countries. Therefore, this research aims to look at the feasibility of a dairy business development in lowland areas area outside Java to support the national " Milk self-sufficiency".

\section{MATERIAL AND METHODS}

The location of the research was the development of the dairy program from the Directorate General of Livestock in the farmer group of "Talago Sakato" Nagari Kayu, Padang Pariaman District, West Sumatera Province. Data collection was done by 2015 in the form of secondary data characterizing the area location of the observation. Other variables are the form of primary data is milk production from all cattle belonging to the group "Talago Sakato" as much as 18 heads, taken each morning and evening, and value of 
the input-output dairy businesses. Descriptive data was used to analyse the location characteristic and non parametric $t$ test was used to compare milk production in this research with the productivity in the Java Island, especially that in the highland and lowland areas. The comparison value is taken from the average production of milk production in Java i.e. the highland area (Lembang) was 17.6 litres/head/day and in the lowland area (Pasuruan) 7.72 litres/head/day (Priyanto et al. 2015). When $n<30$ and $\sigma^{2}$ is unknown, the $\mathrm{t}$ test be used for random samples from normal population. The likelihood ratio technique yields a corresponding test based on test which is a value of a random variable having the $t$ distribution with $n-1$ degrees of freedom.

$$
\left.\begin{array}{l}
\mathrm{H}_{\mathrm{o}}=\mathrm{X}_{\mathrm{i}}=\mu_{0} \\
\mathrm{H}_{\mathrm{a}}=\mathrm{X}_{\mathrm{i}} \neq \mu_{0}
\end{array}\right\} \quad \mathrm{t}=\frac{\mathrm{X}_{\mathrm{i}}-\mu_{0}}{\sigma_{\mathrm{x}} / \sqrt{\mathrm{n}}}
$$

$\mathrm{H}_{\mathrm{o}} \quad=$ Null hypothesis

$\mathrm{H}_{\mathrm{a}} \quad=$ Alternative hypothesis

$\mathrm{X}_{\mathrm{i}}=$ The average productivity of dairy cows in comparison

$\mu_{01}=$ The average productivity of dairy cows in comparison in Java (in the morning) 6 litres/head

$\mu_{02}=$ The average productivity of dairy cows in comparison in Java (in the afternoon) 5 litres/head

$\mu_{03}=$ The average productivity of dairy cows in comparison in Java (total/day) 11 litres/head

$\mu_{04}=$ The average productivity of dairy cows in comparison in the lowland of Java 7.72 litres/head

$\mu_{05}=$ The average productivity of dairy cows in comparison in the highlands of Java 17.6 litres/head

Whereas in analysis of farmer calculated values of $\mathrm{B} / \mathrm{C}$ as an indicator of the appropriateness of a business. $B / C$ is calculated with $(B / C)$ and without labor $\operatorname{cost}\left(B / C_{1}\right)$.

$$
\frac{\mathrm{B}}{\mathrm{C}}=\frac{\mathrm{TR}-\mathrm{TC}}{\mathrm{TC}} \quad \frac{\mathrm{B}}{\mathrm{C}_{1}}=\frac{\mathrm{TR}-\mathrm{TC}_{1}}{\mathrm{TC}_{1}}
$$

TR $=$ Total revenue

$\mathrm{TC}=$ Total cost

$\mathrm{TC}=\mathrm{TC} 1+\mathrm{TC} 2$

$\mathrm{TC} 1=$ Total expenditure costs of feed and equipment

TC2 = Total spending on labor cost

If the value of $\mathrm{B} / \mathrm{C}$ is not profitable, the value of break even point (BEP) for milk production and BEP for labor cost will be calculated.

\section{RESULTS AND DISCUSSION}

\section{The characteristics of the area, the suitability of the agroecosystemfor dairy cows}

Views of the topography of the region, Padang Pariaman consists of $40 \%$ lowland areas in the West which leads to the beach. There are lowland areas to the West which lay along the coast with an altitude between 0-10 metres above sea level, as well as $60 \%$ of the area of the eastern part of which is surging up to the Bukit Barisan. There are undulating hills area to the East at an altitude of 1,000 to $10 \mathrm{~m}$ above sea level. Padang Pariaman has a very short dry season and ocean areas which are strongly influenced by the sea. The hottest air temperature falls in the month of May, while the lowest temperature is in September. 
The total area of $1,684.40$ ha, consists of $44.22 \%$ of the settlement, $36.57 \%$ plantation, $14.48 \%$ rice fields dominated by irrigated rice fields $(10.86 \%)$. This area has high availability of forage grass and food crops waste as livestock feed. In the lowland area of Padang Pariaman, there are some groups of dairy cattle farmers who had funds from the local government. The livestock development was conducted by communal groups.

Table 1. Characteristics of Padang Pariaman District, West Sumatera

\begin{tabular}{lcc}
\hline \hline Variables & Standard value for dairy cattle* & Padang Pariaman** \\
\hline Altitude $(\mathrm{m} \mathrm{dpl})$ & $750-1250$ & $300-400$ \\
Temperature $\left({ }^{\circ} \mathrm{C}\right)$ & $17-22$ & $24.4-25.7$ \\
Relative humidity $(\%)$ & $>55$ & 86.75 \\
Rain fall $(\mathrm{mm}) /($ days/month) & n.a. / n.a. & $368.4 / 19$ \\
Average wind speed (knots/hour) & n.a. & $2: 14$ \\
\hline
\end{tabular}

Source: *Atmadilaga (1959) quoted by Djaja et al. (2009); **Disnak Kabupaten Padang Pariaman (2015)

From Table 1, the development area for dairy cattle is not an ideal location in terms of altitude and temperature of the environment. Air temperature correlated with altitude; the higher the location, the lower the temperature will be. Djaja et al. (2009) said that the average air temperature will decrease $1.7^{\circ} \mathrm{C}$ for each altitude of $305 \mathrm{~m}$ above sea level. From an area like Padang Pariaman, with the same management, it will be predicted to get lower productivity of dairy cattle. Milk productivity of dairy cattles is influenced by genetic factor, quality and quantity of feed management, maintenance and environmental characteristics including the altitude, air temperature and humidity.

According to the Djaja et al. (2009) the air temperature rise will result in an increase in the frequency of the pulse and breathing every minute of it as a reaction of the body's response to the rise in body temperature. An increase in the frequency of the pulse is to speed up the distribution of blood as the transport of oxygen. The increase in temperature decreases the appetite, feed rate of motion and use of energy efficiency and finally decreased milk production as a result. Collier et al. (2006) said that acclimation to thermal stress is now identified as a homeorhetic process under endocrine control. The process of acclimation occurs in two phases (acute and chronic) and involves changes in secretion rate of hormones as well as receptor populations in target tissues. It does not mean dairy cattle can not grow well in the lowland areas. Several efforts can be done in order to achieve the desired productivity, among other things through the adjustment of the shape of the cage, feeding refrigerators solar energy and increase the frequency of feeding (Matondang et al. 2012). Yani et al. (2007) recommended that one of the best design configurations is $6.25 \mathrm{~m}$ height, $8.3 \mathrm{~m}$ width, $0.4 \mathrm{~m}$ height of wall. The best design could decrease $0.474^{\circ} \mathrm{C}$ of air temperature and increase dry matter intake of dairy cattle by 0.403 $\mathrm{kg} /$ day/head. The amount of heat production of $\mathrm{FH}$ was considered to determine the best design of dairy barn. West (2003) also stated that modifications including shade, barns enhance passive ventilation, and the addition of fans and sprinklers increase body heat loss, lowering body temperature and improving DMI.

In addition to these parameters, it has long been known that season of the year has major impacts on dairy animal performance measures including growth, reproduction, and lactation (Collier et al. 2006). Whereas it is known that the difference in altitude will result in the difference of the season/climate. 


\section{Milk production in Talago Sakato}

Measurement of milk production based on recording each cattle milking, 16 heads on lactation phase I and two heads on lactation II. The results of milking can be stated quite good production levels i.e. reaching 10.03 litres/head/day. The result of the morning milking is higher than in the afternoon (5.99 vs 4.04 litres/head) (Table 2). Total production of 18 heads 180.53 litres/day, due in August and September the new dairy cattle birth (11 heads), whereas six heads at the stage of lactation months to V and VI.

Table 2. The average dairy cow milk production in KT Kayu Nagari, Padang Pariaman, 2015

\begin{tabular}{|c|c|c|c|c|c|}
\hline \multirow{2}{*}{ No. of cattle } & \multirow{2}{*}{ Lactation } & \multirow{2}{*}{ Month of lactation } & \multicolumn{3}{|c|}{ Production (litre/day) } \\
\hline & & & Morning & Afternoon & Total \\
\hline 1909 & 1 & 5 & 3.82 & 2.46 & 6.28 \\
\hline 1735 & 1 & 5 & 6.00 & 3.80 & 9.80 \\
\hline 1912 & 1 & 2 & 7.12 & 3.80 & 10.92 \\
\hline 1908 & 1 & 5 & 4.45 & 2.35 & 6.80 \\
\hline 1906 & 1 & 2 & 6.94 & 4.18 & 11.12 \\
\hline 1905 & 1 & 2 & 7.08 & 4.16 & 11.24 \\
\hline 1902 & 2 & 2 & 8.00 & 5.00 & 13.00 \\
\hline 1731 & 1 & 2 & 6.70 & 4.08 & 10.78 \\
\hline 1616 & 1 & 1 & 9.75 & 6.60 & 16.35 \\
\hline 6531 & 1 & 5 & 6.00 & 3.80 & 9.80 \\
\hline 1920 & 1 & 5 & 5.48 & 3.42 & 8.90 \\
\hline 1733 & 1 & 2 & 5.50 & 3.60 & 9.10 \\
\hline 1910 & 1 & 2 & 5.48 & 4.70 & 10.18 \\
\hline 1919 & 2 & 6 & 4.22 & 2.80 & 7.02 \\
\hline 1013 & 1 & 2 & 3.75 & 3.00 & 6.75 \\
\hline 1904 & 1 & 2 & 3.09 & 2.85 & 5.94 \\
\hline 1903 & 1 & 2 & 6.42 & 5.18 & 11.60 \\
\hline 1910 & 1 & 1 & 8.10 & 6.85 & 14.95 \\
\hline$X \min$ & & & 3.09 & 2.35 & 5.94 \\
\hline$X \max$ & & & 9.75 & 6.85 & 16.35 \\
\hline $\mathrm{X}$ mode & & & 6.00 & 3.80 & 9.80 \\
\hline $\mathrm{X}$ median & & & 6.00 & 3.80 & 9.99 \\
\hline Xaverage & & & 5.99 & 4.04 & 10.03 \\
\hline Varians $=\sigma^{2}$ & & & 3.01 & 1.60 & 8.40 \\
\hline St Dev $=\sigma$ & & & 1.73 & 1.27 & 2.90 \\
\hline
\end{tabular}

These conditions indicate that the level of milk production on lactation 1-2 are potentially high production, but it could still be improved because the given feed concentrate is still low. It is also because of the influence of feed supplied by dairy farmers i.e. $3-5 \mathrm{~kg}$ of waste of tofu that mixed with $1 \mathrm{~kg}$ rice bran per day per head. It can be seen that the existing cattle genetic performance are relatively good which a good posture, so it 
can be assumed that the productivity can be increased when the feed concentrates with improved quality are given.

$\mathrm{X}_{\min }$ is obtained from dairy cows from the fifth month of lactation to the opposite value of $X_{\max }$ achieved by new dairy cows in the first month of lactation. This is a normal condition in which milk production at the beginning of the month are high. Generally these dairy cows produce as much total 9.80 as shown in the value $X_{\text {mode }}$ which is the most frequently occurring number in a group of these dairy cattles. The value of these three measures of central tendency $X_{\text {average, }} X_{\text {median, }}$ and $X$ mode are similar , means that the milk production from all these dairy cattle has a symmetrical distribution of a group of numbers not a skewed one. In contrast, the value of the variance $\sigma^{2} 3,01$ about $50 \%$ of the value of $\mathrm{X}_{\text {average, }}$ is quite large. The variation is due to the variation of the time of the month lactation.

Table 3. Comparing milk production in the research lowland area of outside Java (OJ-LL) vs lowlands of Java (J-LL) vs highlands of Java (J-HL)

\begin{tabular}{lccccccc}
\hline \hline Variable & $\mathrm{N}$ & $\begin{array}{c}\text { Mean } \\
(\text { (/day) }\end{array}$ & $\begin{array}{c}\text { Std. } \\
\text { deviation }\end{array}$ & $\begin{array}{c}\text { Std. error } \\
\text { mean }\end{array}$ & $\mathrm{t}$ & $\mu_{0}$ & \multicolumn{1}{c}{$\begin{array}{c}\text { Sig. (2- } \\
\text { tailed) }\end{array}$} \\
\hline Morning-OJ-LL & 18 & 5.994 & 1.733 & 0.408 & -0.001 & 6.00 & 0.989 \\
Afternoon-OJ-LL & 18 & 4.035 & 1.266 & 0.298 & -3.234 & 5.00 & 0.005 \\
Total-OJ-LL & 18 & 10.029 & 2.897 & 0.683 & -1.422 & 11.00 & 0.173 \\
OJ-LL vs J-LL & 18 & 10.029 & 2.897 & 0.683 & 3.382 & 17.60 & 0.009 \\
OJ-LL vs J-HL & 18 & 10.029 & 2.897 & 0.683 & -11.088 & 7.72 & 0.000 \\
\hline
\end{tabular}

It is assumed that in most cases the acquisition of milk production at the level of a breeder in Java Island on the morning of 6 litres/head, afternoon of 5 liter/head and a total of 11 liters a day/head, then milk production conditions in lowlands outside Java is no significantly different for the productivity of the morning as well as total, except in the afternoon has significantly different with P: 0.005 . When compared to productivity in the highlands of Java which has total production 17.60 litres/head/day, the productivity in Nagari Sakato is significantly lower. Since $|t| \geq t_{\alpha / 2, n-1}$, the null hypothesis cannot be rejected. This result is interesting, when milk production of low land Pasuruan (in Java) dairy cattle is significantly lower than production at the lowland Nagari Sakato. It needs further study, namely the genetic, feed or the environment aspects. Further research is required. However, this value indicates that the development of the dairy cows in the lowlands outside Java can be developed further.

The difference of milk composition between location in different altitude was influenced by the differences of botanical composition of grass. In the lowland grassland, the feed was composed only of grasses and legumes and its botanical diversity was distinctly less than that of the highland permanent pastures. With rising altitude, a decrease in the proportion of grasses and an increase in numerous dicotyledonous species were noticed (Collomb et al. 2001). Collomb et al (2002) also stated that type plant is one of the factors linked to the altitude in mountains and highlands and plants could be responsible for the occurrence of the most abundant fatty acids in milk fat.

\section{Analysis of dairy cattle farming system}

The analysis was performed on the group, because dairy cows were raised by a group of 11 people. In January to August milking was only done on 2-4 heads, because the cattle that were given to the farmers were still young so they took time to be mated and gave 
birth. In September some of them gave birth so that the number of cattle that can be milked became 18 heads.

Costs in the business covering the costs of concentrate in the form of rice bran and tofu waste. Tofu waste was given especially in lactation phase i.e. as much as 4-5 $\mathrm{kg} /$ head/day with a price of Rp. 600/kg, given twice a day (morning and afternoon) and 1 $\mathrm{kg}$ rice bran/head/day with a price of $\mathrm{Rp} .2,000 / \mathrm{kg}$. Other costs are for drugs and other things. The calf was given some milk. The cost of equipments and cages Rp. 120,000,000 were funded by the provincial livestock department.The cage was strong/good quality so it can be predictable was able tobe used about 30 years. The cost of depreciation cage is calculated as one of the cost. Taking the grass performed by members of the group in turn (each four people) with a time of about four hours. Economy analysis is calculated with and without labor cost. Actually they were not paid by the group, but in the analysis labor cost was included with the value of the working day people Rp. 25,000/day. Labor costs are also carried out at the time of the cleaning cage, feeding, milking, making compost and the other around the cage.

One of the income source of dairy cattle business obtained from milk which are sold at Rp. 8,000/litres, sales of calves, as well as the sale of compost although not optimal (Table 4). Milk sales done by groups to the cafes in nearby Padang Pariaman, Padang Panjang, and also to the District of Riau Province. There is a small percentage of buyers come directly to the group. Milk prices are high enough Rp. 8,000/litres compared to the selling price of milk in the Island of Java Rp. 4500/litres. The group has also initiated processing compost from cow manure and sold around the site for fertilizer plants vegetables which reached around Rp. 500,000/month.

NCB business value dairy cows conducted group "Talago Sakato" if labor was not taken into account still shows a profit despite relatively small Rp. 27,009,000/groups/year. This occurs because when the farm started in 2013 the cattle is still young, so needs time to be mated and in the end of 2014, there are two heads of lactating cattle and in September 2015 some of them gave birth so they can produce high milk production. From the analysis of the observations over the past year when the labor cost is included calculated, the Cost and Return Analysis (CRA) still show losses are quite high (Rp. $16,701,000 /$ year) (Table 4). But if labor cost is excluded, the cattle business conducted on the group still get a profit Rp. 2.463.454/breeders/year which is equivalent to the revenue of Rp. 205.287/breeders/month.

This indicates that the labor cost is very expensive. Although milk prices high enough compare with the price in Java, it is not sufficient for labor cost. With the present price conditions, the value of BEP of milk production should be increased to be 19.016 litres/year or 1056 litres/head/year or an additional production at least 6 litres/head/day. The condition can also be seen from the value of $\mathrm{B} / \mathrm{C} 0.30$ when the labor cost is excluded. When feed concentrates is improved in quality, it will increase milk production.

This economic value can still be upgraded as research results obtained Sulastri (2002) in Yogyakarta that the total share of dairy income is more than half $(56.3 \%)$ of the total household income. It is relatively high e than the income from crop production (17.5\%) and non-agriculture work (25.4\%). 
Table 4. Analysis of dairy cattle business in a group/year

\begin{tabular}{llr}
\hline \hline Variables & \multicolumn{1}{c}{ Description } & Rp. \\
\hline Expenditure & Concentrate feed & $14,400,000$ \\
& January-August & $72,000,000$ \\
& September-December & $1,230,000$ \\
& Medicinal drugs, etc. & $4,000,000$ \\
\hline & The value of barn tax & $91,630,000$ \\
\cline { 2 - 3 } & Subtotal-1 (TC1) & \\
\cline { 2 - 3 } & Labor cost & $29,200,000$ \\
& grassing (4 orang/4 jam/hari) & $14,600,000$ \\
\hline & maintenance & $43,800,000$ \\
\cline { 2 - 3 } Output & Sub total -2 (TC2) & $135,430,000$ \\
\cline { 2 - 3 } & Total cost (TC1 + TC2) & $109,479,000$ \\
\cline { 2 - 3 } & Milk sales & $3,250,000$ \\
& Calves sales & $6,000,000$ \\
\hline B/C without labor cost & Fertilizer sales & $118,729,000$ \\
\cline { 2 - 3 } Group benefit/year & Total revenue & $27,099,000$ \\
\cline { 2 - 3 } Farmer benefit/year & Net cash benefit (NCB) & $-16,701,000$ \\
& Cost and return analysis (CRA) & $2,463,454$ \\
& Net cash benefit (NCB) & $-1,518,272$ \\
& Cost and return analysis (CRA) & 0.30 \\
& & -0.12 \\
\hline
\end{tabular}

\section{CONCLUSION}

The average milk production of dairy cows in lowland area of Padang Pariaman reached 10 litres/head/day, with a value of $\mathrm{B} / \mathrm{C}_{1} 0.30$ regardless of labor cost. If the labor cost was taken into account, it required the addition of milk productivity 1,056 liters/head/lactation period in order to accomplish BEP. Dairy business in the lowland areas outside Java is quite feasible to be developed but the technology needs to be improved.

\section{REFERENCES}

Collier RJ, Dahl GE, Van Baale MJ. 2006. Major advances associated with environmental effects on dairy cattle. J Dairy Sci. 89:1244-1253.

Collomb M, Butikofer U, Sieber R, Bosset JO, Jeangros B. 2001. Conjugated linoleic acid and trans fatty acid composition of cows milk fat produced in lowlands and highlands. J Dairy Res. 68:519-523.

Collomb M, Bütikofer U, Sieber R, Jeangros B, Bosset JO. 2002. Correlation between fatty acids in cows milk fat produced in the lowlands, mountains and highlands of Switzerland and botanical composition of the fodder. Int Dairy J. 12:661-666. 
Disnak Kabupaten Padang Pariaman. 2015. Laporan Dinas tahun 2015. Padang Pariaman (Indonesia): Dinas Peternakan Kabupaten Padang Pariaman.

Ditjennak. 2008. Kebijakan pemerintah dalam pengembangan agribisnis persusuan dalam menghadapi era pasar bebas. Jakarta (Indonesia): Direktorat Jenderal Peternakan.

Ditjen PKH. 2015. Peternakan dalam angka. Jakarta (Indonesia): Direktorat Jenderal Peternakan dan Kesehatan Hewan.

Djaja W, Matondang RH, Haryono. 2009. Aspek manajemen usaha sapi perah. Dalam: Santosa KA, Diwyanto K, Toharmat, penyunting. profil usaha peternakan sapi perah di Indonesia. Bogor (Indonesia): LIPI Press. p. 27-68.

Gayatri S, Setiadi A, Isbandi, Budihardjo. 2005. Analisis ekonomi pemberian kredit sapi perah di Kecamatan Pakem, Kabupaten Sleman, Yogyakarta. Dalam: Mathius IW, Bahri S, Tarmudji, Prasetyo LH, Triwulanningsih E, Tiesnamurti B, Sendow I, Suhardono, penyunting. Inovasi Teknologi Peternakan untuk Meningkatkan Kesejahteraan Masyarakat dalam Mewujudkan Kemandirian dan Ketahanan Pangan Nasional. Prosiding Seminar Nasional Teknologi Peternakan dan Veteriner. Bogor, 12-13 September 2005. Bogor (Indonesia): Puslitbangnak. hlm. 328-332.

LIPI. 2004. Widya karya nasional pangan dan gizi (WNPG) VIII. Jakarta (Indonesia): LIPI.

Makka D. 2004. Prospek pengembangan sistem integrasi petemakan yang berdaya saing. Dalam: Prosiding Seminar Nasional Integrasi Tanaman Ternak. Denpasar, 20-22 Juli 2005. Bogor (Indonesia): Puslitbangnak bekerjsama dengan BPTP Bali. hlm. 18-31.

Matondang RH, Talib C, Herawati T. 2012. Prospek pengembangan sapi perah di luar Pulau Jawa mendukung swasembada susu di Indonesia. Wartazoa. 22:161-168.

Ministry of Agriculture. 2016. Laporan Tahunan Badan Ketahanan Pangan Tahun 2015. Jakarta (Indonesia): Ministry of Agriculture.

Pambudi R, Sipayung T, Priatna WB, Burhanuddin, Kriswantriyono A, Satria A. 2001. Ideas collection. Bisnis dan kewirausahaan dalam sistem agribisnis. $3^{\text {rd }}$ Ed. Bogor (Indonesia): Pustaka Wirausaha Muda.

Priyanto D, Nasrullah, Isbandi. 2015. Pengembangan usaha ternak sapi perah rakyat di Pulau Jawa (profil, masalah, solusi). Jakarta (Indonesia): IAARD Press.

Purnakarya I. 2009. Peran zat gizi makro terhadap kejadian demensia pada lansia. J Kesehatan Masyarakat Andalas (JKMA). 3:89-92.

Saragih B. 2001. Kumpulan pemikiran. agribisnis. paradigma baru pembangunan ekonomi berbasis pertanian. Jakarta (Indonesia): Yayasan Mulia Persada Indonesia dan PT. Suveyor Indonesia bekaerjasama dengan Pusat Studi Pembangunanan IPB dan Unit for Sosial and Economic Studies and Evaluation (USESE) foundation.

Sulastri E, Maharjan KL. 2002. Role of dairy cooperative services on dairy development in Indonesia a case study of Daerah Istimewa Yogyakarta Province. J Int Dev Coop. 9:17-40.

Yani A, Suhardiyanto H, Hasbullah R, Purwanto BP. 2007. Analisis dan simulasi distribusi suhu udara pada kandang sapi perah menggunakan computational fluid dynamics (CFD). Media Peternakan. 30:218-228.

West JW. 2003. Effects of heat-stress on production in dairy cattle. J Dairy Sci. 86:2131-2144. 


\section{DISCUSSION}

\section{Questions}

1. From the results of this research, can a dairy cattle business in the lowlands be developed?

2. Why should the farm be located outside Java?

\section{Answers}

1. Yes it can. However, the right technologies have to be applied to increase both productivity and value $B / C$.

2. Because land areas outside Java are quite extensive, have abundant feed and forage resource and also milk demand are high. 